\title{
Endogenous thyrocyte-produced nitric oxide inhibits iodide uptake and thyroid-specific gene expression in FRTL-5 thyroid cells
}

\author{
Laura Fozzatti, María L Vélez, Ariel M Lucero, Juan P Nicola, Iván D Mascanfroni, Daniela R Macció, \\ Claudia G Pellizas, Germán A Roth and Ana M Masini-Repiso
}

Centro de Investigaciones en Bioquímica Clínica e Inmunología-(CIBICl) Consejo Nacional de Investigaciones Científicas y Técnicas (CONICET), Departamento de Bioquímica Clínica, Facultad de Ciencias Químicas, Universidad Nacional de Córdoba, Haya de la Torre y Medina Allende, 5000 Córdoba, Argentina

(Requests for offprints should be addressed to A M Masini-Repiso; Email: amasini@fcq.unc.edu.ar)

\begin{abstract}
Nitric oxide (NO) is a free radical that mediates a wide array of cell functions. It is generated from L-arginine by NO-synthase (NOS). Expression of NOS isoforms has been demonstrated in thyroid cells. Previous reports indicated that $\mathrm{NO}$ donors induce dedifferentiation in thyrocytes. However, the functional significance of endogenous thyrocyte-produced NO has not been explored. This work aimed to study the influence of endogenous $\mathrm{NO}$ on parameters of thyroid cell function and differentiation in FRTL-5 cells. We observed that treatment with the NOS inhibitor, N $\omega$-nitroL-arginine methyl ester (L-NAME), increased the TSHstimulated iodide uptake. The TSH-induced sodium iodide symporter (NIS) and thyroglobulin (TG) mRNA expressions were increased after incubation with L-NAME. In transient
\end{abstract}

transfection assays, TSH-stimulated transcriptional activities of NIS and TG promoters were increased by L-NAME. An increment of the TSH-stimulated cell proliferation was observed after NOS inhibition. Similar results were obtained when the action of another NOS inhibitor, $N^{g}$-monomethylL-arginine, was analysed for most of these studies. The production of NO, which was not detectable in basal conditions, was increased by TSH. Our data provide strong evidence that endogenous $\mathrm{NO}$ could act as a negative signal for TSH-stimulated iodide uptake and thyroid-specific gene expression as well as proliferation in thyrocytes. These findings reveal a possible new inhibitory pathway in the regulation of thyroid cell function.

Journal of Endocrinology (2007) 192, 627-637

\section{Introduction}

Nitric oxide (NO) is a versatile molecule with a wide spectrum of effects in several tissues (Laskin et al. 1994, Guix et al. 2005). The synthesis of NO is catalysed by NO synthase (NOS). Three isoforms of NOS (I-III) have been well characterized, which are widely expressed in most cell types. The NOS-mediated reaction involves L-arginine oxidation with generation of NO and L-citrulline (Nathan \& Xie 1994, Guix et al. 2005). One of the physiologically more relevant targets of NO is the soluble guanylyl cyclase. The binding of $\mathrm{NO}$ to this enzyme leads to the formation of $3^{\prime}, 5^{\prime}$-cyclic guanosine monophosphate (cGMP), which is involved in the activation of a variety of effectors including cGMP-dependent protein kinase (cGK; Krumenacker et al. 2004).

Thyroid hormone biosynthesis involves iodide uptake by the sodium iodide symporter (NIS) with later iodination of thyroglobulin (TG) by the action of thyroid peroxidase (TPO). All these events are regulated by thyrotrophin (TSH) mainly by the modulation of thyroid-specific genes, such as NIS, TG and TPO (Dunn \& Dunn 2001).

The existence of a basal tonic level of endogenous NO generation with a possible autocrine or paracrine role in the thyroid tissue has been proposed (Esteves et al. 1992). Thus, evidence has been obtained for a cGMP increase mediated by endogenous NO in dog thyroid slices (Esteves et al. 1992). The three isoforms of NOS have been detected in the rat thyroid gland being the greatest level of basal expression displayed by NOS III (Colin et al. 1995). It has been demonstrated that NOS III is expressed in the thyroid follicular cell (Colin et al. 1997).

Several effects of $\mathrm{NO}$ on thyroid function have been demonstrated using $\mathrm{NO}$ donors. We previously reported that the NO donors, sodium nitroprusside (SNP) and $S$-nitrosoglutathione, inhibited iodide uptake, organification and transport in bovine thyroid cells (Costamagna et al. 1998). In accordance, SNP reduced iodide uptake in primary cultures of calf thyrocytes (Bocanera et al. 1997). It has been reported that SNP increased the cGMP production in dog (Esteves et al. 1992), human (Millatt et al. 1993) and calf (Bocanera et al. 1997) thyroid cells. The NO generation induced by $\mathrm{NO}$ donors would resemble what might occur in some abnormal conditions of thyroid tissue in which increased levels of NO could contact with thyrocytes. Nevertheless, the functional significance of the endogenous thyrocyte-generated NO has not been examined. 
In several cell types, the role of endogenous NO production has been extensively studied by manipulation of biological activity of NOS with NOS inhibitors. NOS is competitively inhibited by L-arginine analogues including $\mathrm{N} \omega$-nitro-Larginine methyl ester (L-NAME) and $N^{\mathrm{g}}$-monomethyl-Larginine (L-NMMA) (Alderton et al. 2001, Albrecht et al. 2003). In the present study, we analysed the significance of the endogenously generated $\mathrm{NO}$ on the regulation of some TSH-stimulated parameters of function, differentiation and proliferation by inhibition of NOS with L-NAME and L-NMMA. The effect of TSH on NO production in the thyroid cell was also examined.

\section{Materials and Methods}

\section{Cell culture}

FRTL-5 rat thyroid cells (ATCC CRL 8305; American Type Culture Collection) were kindly provided by Dr L Kohn (Edison Biotech Institute, Ohio University, USA) and had the properties reported previously (Ambesi-Impiombato et al. 1980). Cells were grown in a $5 \% \mathrm{CO}_{2}-95 \%$ air atmosphere in Coon's modified Ham F-12 medium (DMEM/Ham F-12, 1:1), supplemented with $5 \%$ calf serum (PAA Laboratories $\mathrm{GmbH}$, Linz, Austria), $1 \mathrm{mIU} / \mathrm{ml}$ bovine TSH (a generous gift of the NIDKK National Pituitary Hormone Program \& Dr AF Parlow, NIH, Baltimore, MD, USA), $10 \mu \mathrm{g} / \mathrm{ml}$ bovine insulin, $5 \mu \mathrm{g} / \mathrm{ml}$ bovine transferrin, $2 \mu \mathrm{mol} / \mathrm{ml}$ glutamine, antibiotics and an antimycotic (Sigma). Cells were passaged every 7-8 days and fed fresh medium every 23 days. When they reached $70 \%$ of confluence, the cells were shifted to medium without TSH (basal medium) containing $0 \cdot 2 \%$ calf serum and maintained for $5-7$ days before the experiments (Vélez et al. 2006). Starved (basal) cells were treated with the indicated concentration of TSH in the presence or absence of the NOS inhibitors L-NAME $(1 \mathrm{mM})$ or L-NMMA $(0.1 \mathrm{mM}$; Sigma) or the cGK inhibitor KT-5823 $(5 \mu \mathrm{M})$ (Calbiochem, San Diego, CA, USA) for different periods of time. All cultured cells were used before passage 20 .

\section{Iodide uptake}

The iodide uptake assay was performed as described (Costamagna et al. 1998) with minor modifications. Briefly, FRTL-5 cells seeded in 24-well tissue culture plates were incubated with $0 \cdot 1 \mathrm{Na}^{131} \mathrm{I}$ (carrier-free) and $1 \mu \mathrm{mol} / 1 \mathrm{KI}$ in Hank's Balanced Salt Solution (HBSS) for $35 \mathrm{~min}$ at $37^{\circ} \mathrm{C}$. Thereafter, cells were washed, scraped and centrifuged at $1500 \mathrm{~g}$ for $10 \mathrm{~min}$. Iodide uptake was determined by measuring the total radioactivity incorporated into the cells and expressed as counts/minute per microgram DNA.

\section{DNA content analysis}

The DNA content was measured in the cellular pellet by the diphenylamine method of Burton (1956) modified by Kohn \& Valente (1989).

\section{$R N A$ isolation}

Total RNA was purified from FRTL-5 cells by the acid guanidinium thiocyanate/phenol/chloroform extraction procedure of Chomczynski \& Sacchi (1987). Briefly, the cells were harvested in a denaturing solution containing $4 \mathrm{M}$ guanidine thiocyanate. The suspension was mixed sequentially with $2 \mathrm{M}$ sodium acetate ( $\mathrm{pH} 4$ ), phenol and chloroform/isoamyl alcohol. The mixture was centrifuged, yielding an upper aqueous phase containing total RNA. Following isopropanol precipitation, the RNA pellet was redissolved in the denaturing solution, reprecipitated with isopropanol, washed with 75\% ethanol and dissolved in RNase-free water.

\section{Northern blot analysis}

Total RNA $(20 \mu \mathrm{g})$ was subjected to electrophoresis on $1 \%$ agarose gels containing 0.66 M formaldehyde (Sigma). RNA was transferred to nylon membranes (Sigma) by capillary transblotting overnight. Membranes were baked for $2 \mathrm{~h}$ at $80^{\circ} \mathrm{C}$ and stained with methylene blue to reveal the integrity of RNA and sample loading. Membranes were hybridized overnight at $42{ }^{\circ} \mathrm{C}$ in a solution containing $\alpha^{32} \mathrm{P}$-ATP-probes labelled by random primer methodology (Sambrook et al. 1989). Rat TG (Di Lauro et al. 1982) and NIS (Dai et al. 1996) cDNAs were used as probes. Blots were washed in $2 \times \mathrm{SSC} / 1 \%$ $\mathrm{SDS}$ at room temperature, twice with each one in $2 \times \mathrm{SSC} / 1 \%$ SDS and $0 \cdot 2 \times \mathrm{SSC} / 1 \% \mathrm{SDS}$ at $55^{\circ} \mathrm{C}$. Then, the membranes were exposed to Kodak X-Omat film at $-80^{\circ} \mathrm{C}$ and band intensities determined by scanning densitometry (Scion Image software, Scion Corporation, Fredrick, MD, USA).

\section{Semiquantitative RT-PCR}

cDNA was synthesized from $1 \mu \mathrm{g}$ total RNA. A semiquantitative multiplex RT-PCR was designed to compare the RT-PCR products of the NIS gene with those of the glyceraldehyde-3-phosphate dehydrogenase (GAPDH) gene to determine their relative expression levels. PCR was performed in a $20 \mu \mathrm{l}$ reaction volume containing $2 \mu \mathrm{l}$ cDNA reaction, $0.5 \mu \mathrm{M}$ of each primer, $0.25 \mathrm{mM}$ of each dNTP, $1.5 \mathrm{mM} \mathrm{MgCl}_{2}$ and $0 \cdot 8$ units Taq polymerase. The mixed samples were heated to $95^{\circ} \mathrm{C}$ for $4 \mathrm{~min}$ and then subjected to 29 cycles of amplification performed as follows: denaturation at $95^{\circ} \mathrm{C}$ for $30 \mathrm{~s}$, annealing at $59^{\circ} \mathrm{C}$ for $30 \mathrm{~s}$ and extension at $72{ }^{\circ} \mathrm{C}$ for $30 \mathrm{~s}$, followed by a $7 \mathrm{~min}$ extension at $72{ }^{\circ} \mathrm{C}$ after the last cycle. Primer oligonucleotides for the rat NIS gene were: $5^{\prime}$-GCTGTGGCATTGTCATGTTC (forward) and 5'-TGAGGTCTTCCACAGTCACA (reverse). The amplification yielded a $219 \mathrm{bp}$ DNA product whose 
sequence corresponded to that of fragment 1002-1220 of the rat NIS gene (Dai et al. 1996). The identity of the NIS amplicon was confirmed by automatic sequencing analysis. Primer oligonucleotides for the rat GAPDH gene were: 5'-GAGTATGTCGTGGAGTCTACTG (forward) and 5'-GCTTCACCACCTTCTTGATGTC (reverse). The amplification yielded a $514 \mathrm{bp}$ DNA product corresponding to fragment $1120-1633$ of the rat GAPDH gene, as reported in the Gene Bank (Accession number AF106860). To ensure that the amplification of both rat NIS and rat GAPDH remained within the exponential range, reaction conditions were optimized by assessing the variation in signal intensity for the two genes at various sample amounts and cycle numbers. Three different primer ratios were tested to achieve the same efficiency of amplification, and the ratio 1:1 (NIS:GAPDH) was selected. The primers of rat GAPDH were added after the first 10 cycles of the reaction. Genomic DNA contamination was excluded since extra bands were not observed although the primer pairs used for NIS and GADPH spanned introns. As negative control, reactions without reverse transcription were carried out in parallel. PCR products were separated on $1.5 \%$ agarose gel and visualized with ethidium bromide. The bands of a positive film were scanned, and the density and width of each band measured using the Scion Image software. All primers were from Sigma-Genosys.

\section{Promoter constructs}

pTG Luc construct contained the minimal wild-type promoter of the rat TG gene $(-168$ to $+36 \mathrm{bp})$ linked to luciferase (Luc) reporter gene cloned in the pGL2-Basic plasmid (Kang et al. 2001) and pNIS Luc corresponded to the NIS promoter region from -2841 to $+13 \mathrm{bp}$ linked to Luc gene cloned in the pBSLUC2 plasmid (Garcia \& Santisteban 2002). As negative control, the promoterless pGL3-Basic (Promega) was used. The cytomegalovirus promoter linked to $\beta$-galactosidase gene plasmid (CMV- $\beta$ gal) (Promega) was used to monitor transfection efficiency.

\section{Transfection assays}

FRTL-5 cells were plated at a density of $6 \times 10^{5}$ per $60 \mathrm{~mm}$ diameter tissue culture dish $48 \mathrm{~h}$ before transfection. The calcium phosphate DNA co-precipitation method was used for transfections as previously described (Vélez et al. 2006). Cells were incubated with the precipitate containing $4 \mu \mathrm{g}$ construct of interest and $0 \cdot 8 \mu \mathrm{g}$ CMV- $\beta$ gal. Transfected cells were cultured in basal medium for 5 days and then treated with TSH in the presence or absence of NOS inhibitors. After the indicated time, the cells were harvested in PBS solution, centrifuged and resuspended in passive lysis buffer (Promega). Lysates were centrifuged, and the supernatants assayed for Luc and $\beta$ gal activities as described (Brasier $e t$ al. 1989, Endo et al. 1997).

\section{$\left.{ }^{3} \mathrm{H}\right]$ Thymidine incorporation}

The $\left[{ }^{3} \mathrm{H}\right]$ thymidine incorporation measurement was performed as described previously (Ambesi-Impiombato et al. 1980 ) with minor modifications. FRTL-5 cells were seeded in 96-well plates at a density of $8 \times 10^{3}$ cells/well and when they reached approximately $40 \%$ confluence they were shift to basal medium for 4 days. Then, TSH was added alone or in combination with NOS inhibitors in the presence of $\left[{ }^{3} \mathrm{H}\right]$ thymidine $(1 \mu \mathrm{Ci} /$ well $)$ for $24-48 \mathrm{~h}$ at $37^{\circ} \mathrm{C}$ in a $95 \%$ air $-5 \% \mathrm{CO}_{2}$ atmosphere. After incubation, cells were washed and harvested onto glass fibre filters (Whatman 934-4-H, Whatman Paper Ltd, Maidstone, UK) and the radioactivity incorporated into the dried cells was evaluated by liquid scintillation counting. All determinations were made in quadruplicate and expressed as counts per minute $\left[{ }^{3} \mathrm{H}\right]$ thymidine/well.

\section{CFSE-based proliferation assay}

FRTL- 5 cells were cultured in basal medium for 2 days and then labelled with carboxyfluorescein diacetate succinimidyl ester (CFSE) as described (Wang et al. 2005) with modifications. Briefly, cells cultured in basal medium were harvested, centrifuged and resuspended in PBS. The $5 \mathrm{mM}$ CFSE stock solution (Cat. no. C-1157, Molecular Probes, Carlsbad, CA, USA) was diluted in PBS containing 5\% of fetal bovine serum (FBS) in a total volume of $1 \mathrm{ml}$. CFSE was added to the cell suspension at $7 \cdot 5 \mu \mathrm{M}$ final concentration and incubated for $30 \mathrm{~min}$ at room temperature. The labelled cells were washed twice with basal medium supplemented with 5\% FBS, plated at a density of $3 \times 10^{6}$ per $100 \mathrm{~mm}$ diameter tissue culture dish in basal medium for 3 additional days and then treated with TSH with or without NOS inhibitors. Data were acquired on a Cytoron Absolute cytometer (Ortho Diagnostic System, Raritan, NJ, USA) and analysed using WinMDI $2 \cdot 8$ software (J Trotter, Scripps Institute, La Jolla, CA, USA).

\section{NO production}

Cells were loaded with L- $\left[{ }^{14} \mathrm{C}\right]$ arginine and the amount of L$\left[{ }^{14} \mathrm{C}\right]$ citrulline generated was quantified to estimate NO production by a modification of the previously described technique (Grider 1993). As L-citrulline and $\mathrm{NO}$ are produced in a 1:1 ratio from L-arginine by the action of NOS, L-citrulline synthesis represents a sensitive marker of NO formation. L- $\left[{ }^{[4} \mathrm{C}\right]$ arginine $(0 \cdot 1 \mu \mathrm{Ci})$ was added to the culture medium for $30 \mathrm{~min}$ at $37^{\circ} \mathrm{C}$. Then the cells were scraped and centrifuged for $10 \mathrm{~min}$. Supernatants were transferred to $1 \mathrm{ml}$ columns of Dowex AG50W-X8 $\left(\mathrm{Na}^{+}\right.$ form) and the $\left[{ }^{14} \mathrm{C}\right]$ citrulline was eluted with water. The radioactivity corresponding to the $\left[{ }^{14} \mathrm{C}\right]$ citrulline in the eluate was measured by liquid scintillation counting and normalized by micrograms of DNA. Results were expressed as percentage increase above the basal levels measured in cells cultured in the absence of TSH. 


\section{Statistical analysis}

Analysis of multiple inter-group differences was conducted by one-way ANOVA. As post-test, the Student-Newman-Keuls multiple comparisons test was used. Differences were considered significant at $P<0 \cdot 05$.

\section{Results}

\section{NOS inhibition increased the TSH-stimulated iodide uptake}

To study the possible involvement of the endogenously produced $\mathrm{NO}$ on the regulation of iodide uptake, a crucial step in thyroid hormone biosynthesis, cells were treated with the NOS inhibitor, L-NAME. As expected, TSH (100-1000 $\mu \mathrm{IU} / \mathrm{ml})$ stimulated iodide uptake in FRTL-5 cells (Fig. 1A). The incubation of cells
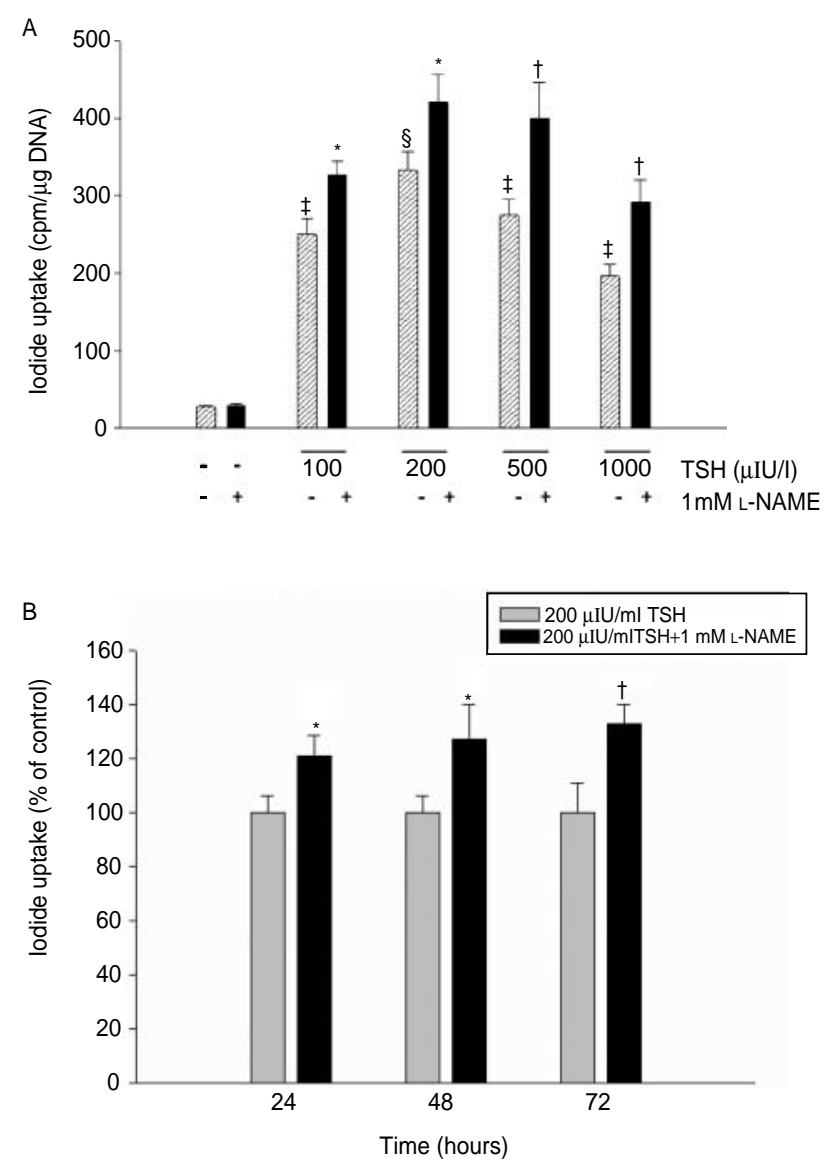

Figure 1 L-NAME treatment increased the TSH-stimulated iodide uptake. (A) Basal FRTL-5 cells were treated with TSH (100$1000 \mu \mathrm{lU} / \mathrm{ml}$ ) alone or in the presence of $1 \mathrm{mM} \mathrm{L}-\mathrm{NAME}$ for $48 \mathrm{~h}$. Values were expressed as counts/min per mg DNA. (B) Basal FRTL-5 cells were treated with TSH $(200 \mu \mathrm{lU} / \mathrm{ml})$ with or without $1 \mathrm{mM}$ L-NAME for 24, 48 and $72 \mathrm{~h}$. Data are expressed as percentage of TSH alone value (taken as $100 \%$ ). Data represent the mean \pm S.E.M. of three independent experiments. ${ }^{*} P<0 \cdot 05,{ }^{\dagger} P<0 \cdot 01$ vs TSH;

${ }^{\ddagger} P<0 \cdot 05,{ }^{\$} P<0 \cdot 01$ vs basal (without TSH); Student-Newman-Keuls multiple comparisons test. with L-NAME $(1 \mathrm{mM})$ in the presence of TSH for $48 \mathrm{~h}$ significantly increased the TSH-induced iodide uptake (Fig. 1A). Since the maximal stimulation of iodide uptake was observed with $200 \mu \mathrm{IU} / \mathrm{ml} \mathrm{TSH}$, this concentration of TSH was used for time-course experiments and to analyse the other functional parameters. An increase of the TSHinduced iodide uptake was observed in the presence of LNAME at 24, 48 and $72 \mathrm{~h}$ (Fig. 1B). Treatment with L-NAME $(1 \mathrm{mM})$ alone did not modify iodide uptake when compared with basal values (Fig. 1A). These findings seem to indicate that endogenous NO exerts an inhibitory effect on TSHstimulated iodide uptake.

The cGK inhibitor, KT-5823, increased the TSH-stimulated iodide uptake

To investigate whether a cGK-dependent mechanism is involved in the NO-induced inhibition of iodide uptake, the action of a specific cGK inhibitor, KT-5823 was assayed. Basal FRTL-5 cells were incubated with TSH $(200 \mu \mathrm{IU} / \mathrm{ml})$ in the presence of $5 \mu \mathrm{M}$ KT-5823 for $48 \mathrm{~h}$. As shown in Fig. 2, KT5823 significantly increased the TSH-stimulated iodide uptake, suggesting the involvement of the cGMP/cGK pathway in the effect of NO. Treatment with KT-5823 alone did not modify iodide uptake when compared with basal values (Fig. 2).

\section{NOS inhibition increased the TSH-induced NIS $m$ RNA expression}

In order to further explore the molecular mechanism involved in NO action on iodide uptake, NIS mRNA level was analysed by northern blot. A single NIS transcript $(2 \cdot 8 \mathrm{~kb})$ was revealed. We found that the treatment of cells with L-NAME increased the TSH $(200 \mu \mathrm{IU} / \mathrm{ml})$-stimulated NIS mRNA level at $48 \mathrm{~h}$ (Fig. 3A). Densitometric analysis of northern blot indicated that NIS mRNA was significantly

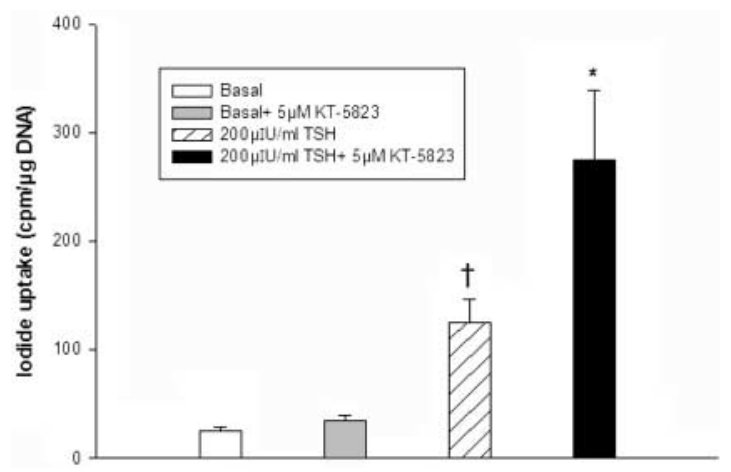

Figure 2 KT-5823 increased the TSH-stimulated iodide uptake. Basal FRTL-5 cells were treated with TSH $(200 \mu \mathrm{IU} / \mathrm{ml})$ alone or in the presence of $5 \mu \mathrm{M} \mathrm{KT}-5823$ for $48 \mathrm{~h}$. Values were expressed as counts/min per mg DNA. Data represent the mean \pm s.E.M. of three independent experiments. ${ }^{*} P<0.01$ vs $\mathrm{TSH}^{+}{ }^{+} P<0.05$ vs basal (without TSH); Student-Newman-Keuls multiple comparisons test. 
A

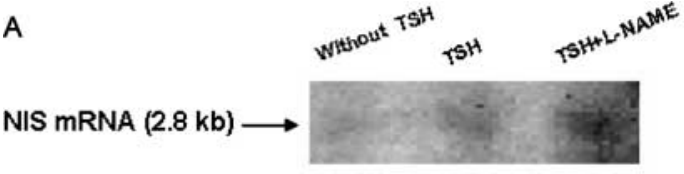

$18 \mathrm{~S}$ rRNA $(1.9 \mathrm{~kb}) \longrightarrow$

B

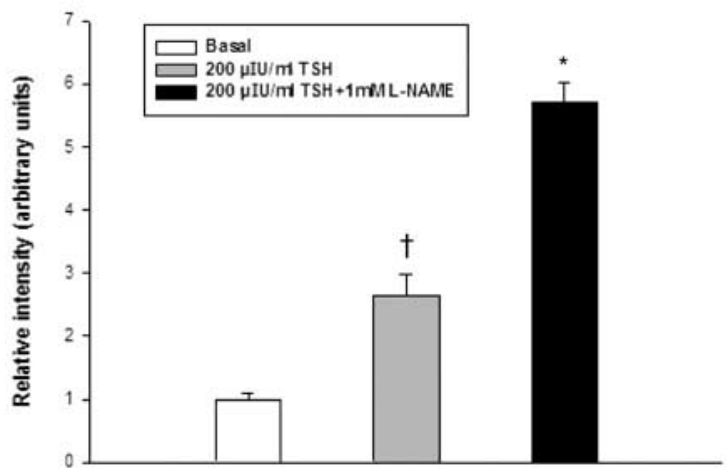

C

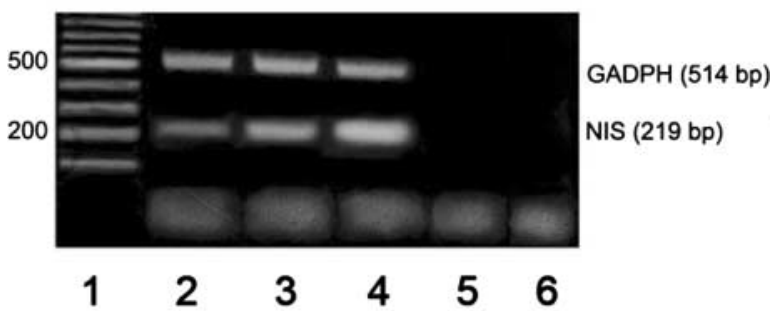

D

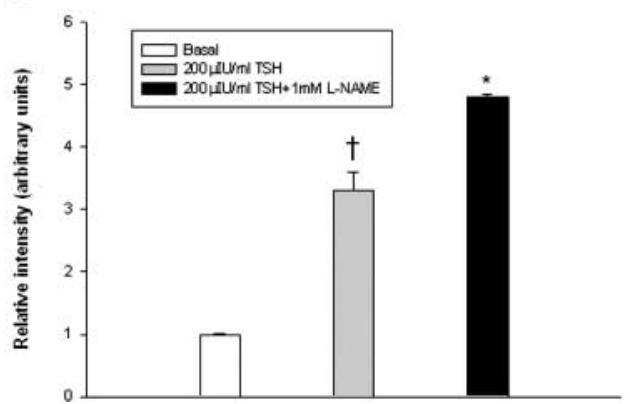

Figure 3 L-NAME treatment increased TSH-induced NIS mRNA expression. Basal cells were treated with $200 \mu \mathrm{IU} / \mathrm{ml}$ TSH alone or in the presence of $1 \mathrm{mM} \mathrm{L-NAME}$ for $48 \mathrm{~h}$. (A) Representative northern blot $(20 \mu \mathrm{g})$ hybridized with rat NIS cDNA probe (upper panel). (B) Densitometric analysis of northern blot. Values were normalized to $18 \mathrm{~S}$ rRNA. (C) Representative NIS RT-PCR. The lower bands represent NIS-specific product (219 bp) and the upper bands GADPH product (514 bp). Lanes represent: 1, molecular weight marker (100 bp ladder), 2, basal cells (without TSH); 3, $200 \mu \mathrm{IU} / \mathrm{ml}$ TSH alone; 4, $200 \mu \mathrm{lU} / \mathrm{ml} \mathrm{TSH}+\mathrm{L}-\mathrm{NAME} ; 5$, no reverse transcription; 6, reverse transcription without RNA. (D) Densitometric analysis of NIS RT-PCR. Data are expressed as the level of NIS mRNA relative to GADPH mRNA. Each value represents the mean \pm S.E.M. of three independent experiments. Basal value was taken as 1.00. ${ }^{*} P<0.01$ vs TSH alone; ${ }^{\dagger} P<0.05$ vs basal (without TSH); Student-Newman-Keuls multiple comparisons test. augmented by L-NAME (Fig. 3B). The increase of NIS mRNA level induced by L-NAME was verified by semiquantitative RT-PCR under similar conditions of cell treatment. A specific PCR product was detected in all samples analysed (Fig. 3C). In accordance with northern blot results, RT-PCR analysis revealed that L-NAME produced a significant increase of TSH-induced NIS mRNA (Fig. 3D). Treatment with L-NAME $(1 \mathrm{mM})$ alone did not modify NIS mRNA level in northern blot or RT-PCR when compared with basal values (data not shown). These findings were in accordance with the stimulation of the TSH-induced iodide uptake observed after NOS blockage and suggested that the NO-mediated inhibition of iodide uptake could involve a reduction of NIS expression.

\section{NOS inhibition increased the TSH-stimulated NIS promoter functional activity}

To study the mechanism by which NO could inhibit NIS mRNA expression, we analysed the functional activity of the NIS promoter in the presence of the NOS inhibitor, L-NMMA. Transient transfection assays were performed with a Luc reporter gene under the regulation of the rat NIS promoter region from -2841 to +13 bp (pNIS Luc; Fig. 4A) (Garcia \& Santisteban 2002). Figure 4B shows the stimulatory effect of TSH on pNIS Luc promoter activity as it is known (Garcia \& Santisteban 2002). After incubation with L-NMMA for $24 \mathrm{~h}$, we observed an increase of the TSH-stimulated pNIS Luc activity (Fig. 4B). Treatment with L-NMMA (0.1 mM)

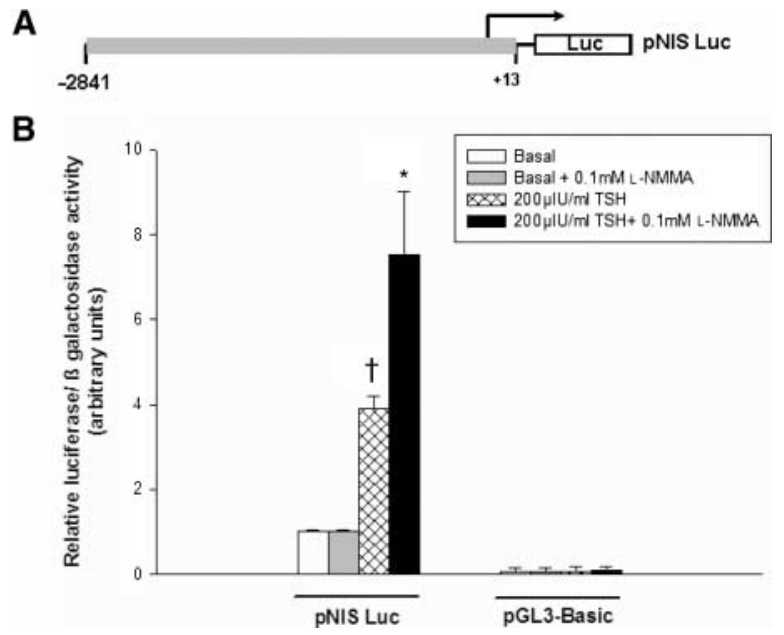

Figure 4 L-NMMA increased the TSH-stimulated NIS promoter activity. (A) Schematic drawing of pNIS Luc containing the rat NIS promoter linked to Luc reporter gene. (B) FRTL-5 cells were transfected with $4 \mu \mathrm{g}$ pNIS Luc and $0 \cdot 8 \mu \mathrm{g}$ CMV- $\beta$ gal. After transfection, cells were maintained for 5 days in basal medium and then treated with TSH alone or in the presence of $0.1 \mathrm{mM} \mathrm{L-NMMA}$ for $24 \mathrm{~h}$. Relative Luc/ßgal activity is expressed as $x$-fold induction over the value of basal cells (taken as 1.00). Data represent the mean \pm S.E.M. of at least three independent experiments. ${ }^{*} P<0 \cdot 01$ vs TSH alone; ${ }^{\dagger} P<0.05$ vs basal (without TSH); Student-NewmanKeuls multiple comparisons test. 
alone did not modify pNIS Luc promoter activity when compared with basal values (Fig. 4B). Similar results were obtained using the other NOS inhibitor, L-NAME (data not shown). These results provide evidence for an inhibitory effect of NO on NIS promoter activity that may account for the reduced NIS mRNA levels induced by NO.

\section{NOS inhibition increased the TSH-stimulated TG $m$ RNA expression}

We evaluated the effect of the endogenous thyrocyte-produced $\mathrm{NO}$ on the expression of TG, another key gene for normal thyroid function. It was observed that treatment of cells with L-NAME (1 mM) significantly increased the TSH-stimulated TG mRNA expression at $48 \mathrm{~h}$ (Fig. 5A and B). Similar results were obtained with other NOS inhibitor, L-NMMA (data not shown). These observations together with those obtained for NIS expression support a role of endogenous $\mathrm{NO}$ in controlling thyroid-specific gene expression.

\section{NOS inhibition increased the TSH-stimulated TG promoter activity}

In order to analyse whether the NO-mediated negative effect on TG mRNA expression could involve a

A

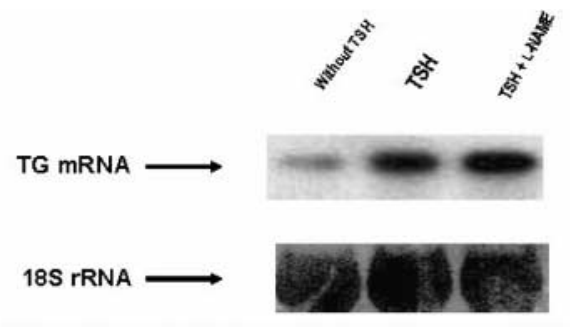

B

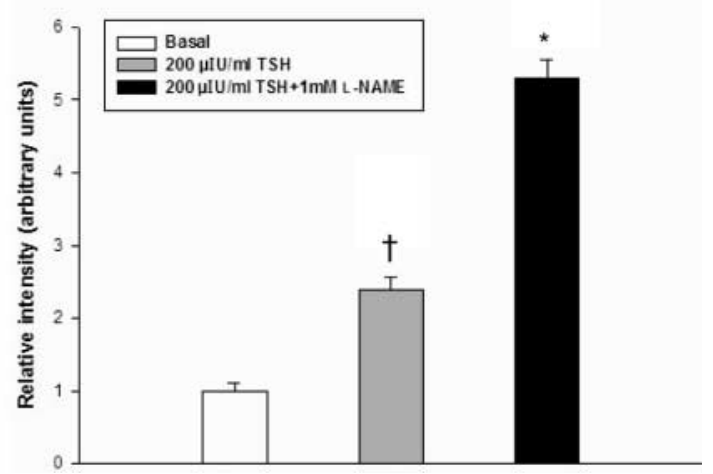

Figure 5 L-NAME treatment increased TSH-stimulated TG mRNA expression. Basal cells were treated with $200 \mu \mathrm{lU} / \mathrm{ml} \mathrm{TSH}$ alone or in the presence of $1 \mathrm{mM}$ L-NAME for $48 \mathrm{~h}$. (A) Representative northern blot $(20 \mu \mathrm{g})$ hybridized with rat TG cDNA probe (upper panel) and 18S rRNA (lower panel) probes. (B) Densitometric analysis of northern blot. Values were normalized to $18 \mathrm{~S}$ rRNA. Each value represents the mean \pm S.E.M. of at least three independent experiments. Basal value was taken as $1 \cdot 00$. ${ }^{*} P<0 \cdot 01$ vs TSH alone; ${ }^{+} P<0.05$ vs basal (without TSH); Student-Newman-Keuls multiple comparisons test. transcriptional mechanism, we evaluated the TSH-induced TG promoter activity under endogenous $\mathrm{NO}$ inhibition. A Luc reporter construct containing the minimal rat $\mathrm{TG}$ promoter from -168 to $+36 \mathrm{bp}$ (pTG Luc; Fig. 6A) (Kang et al. 2001) was transiently transfected to FRTL-5 cells. We observed that the L-NMMA-induced NOS inhibition increased the TSH-stimulated transcriptional activity of pTG Luc at 12 and $24 \mathrm{~h}$ (Fig. 6B). Similar results were obtained in the presence of L-NAME $(1 \mathrm{mM})$ for $24 \mathrm{~h}$ (Fig. 6C). Treatment with L-NAME (1 mM) or L-NMMA $(0.1 \mathrm{mM})$ alone did not modify pTG Luc activity when
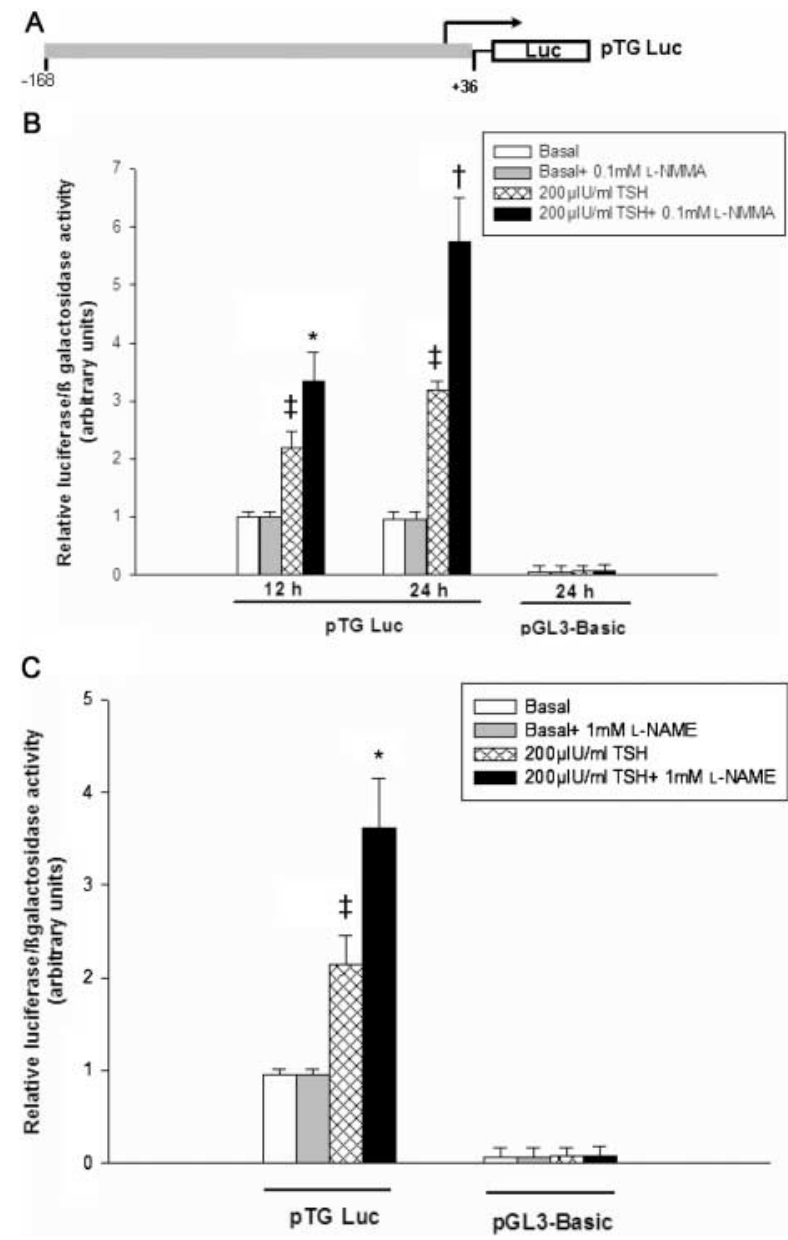

Figure 6 NOS inhibitors increased TSH-stimulated TG promoter activity. (A) Schematic drawing of pTG Luc containing the rat TG promoter linked to Luc reporter gene. (B) FRTL-5 cells were transfected with $4 \mu \mathrm{g}$ pTG Luc and $0.8 \mu \mathrm{g}$ CMV- $\beta$ gal. After transfection, cells were maintained for 5 days in basal medium and then treated with $200 \mu \mathrm{lU} / \mathrm{ml}$ TSH alone or with $0 \cdot 1 \mathrm{mM}$ L-NMMA for 12 and $24 \mathrm{~h}$. (C) Cells transfected as indicated in B were treated with $200 \mu \mathrm{lU} / \mathrm{ml} \mathrm{TSH}$ with or without $1 \mathrm{mM} \mathrm{L-NAME}$ for $24 \mathrm{~h}$. Relative Luc/Bgal activity is expressed as $x$-fold induction over the value of basal cells (taken as 1-00). Data represent the mean \pm S.E.M. of at least three independent experiments. ${ }^{*} P<0 \cdot 05,{ }^{+} P<0 \cdot 01 \mathrm{vs}$ TSH alone; ${ }^{\ddagger} P<0 \cdot 05$ vs basal (without TSH); Student-NewmanKeuls multiple comparisons test. 
compared with basal values (Fig. 6B and C). These results provided evidence for an inhibitory effect of the endogenous $\mathrm{NO}$ on thyroid-specific gene expression at transcriptional level.

\section{NOS inhibition increased the TSH-stimulated cell proliferation}

It has been reported that NO regulates the growth of different cell types in a dual manner. We examined whether the endogenously produced NO could influence the TSHstimulated thyroid cell proliferation. Two different approaches were used to evaluate the cell proliferation, the $\left[{ }^{3} \mathrm{H}\right]$ thymidine
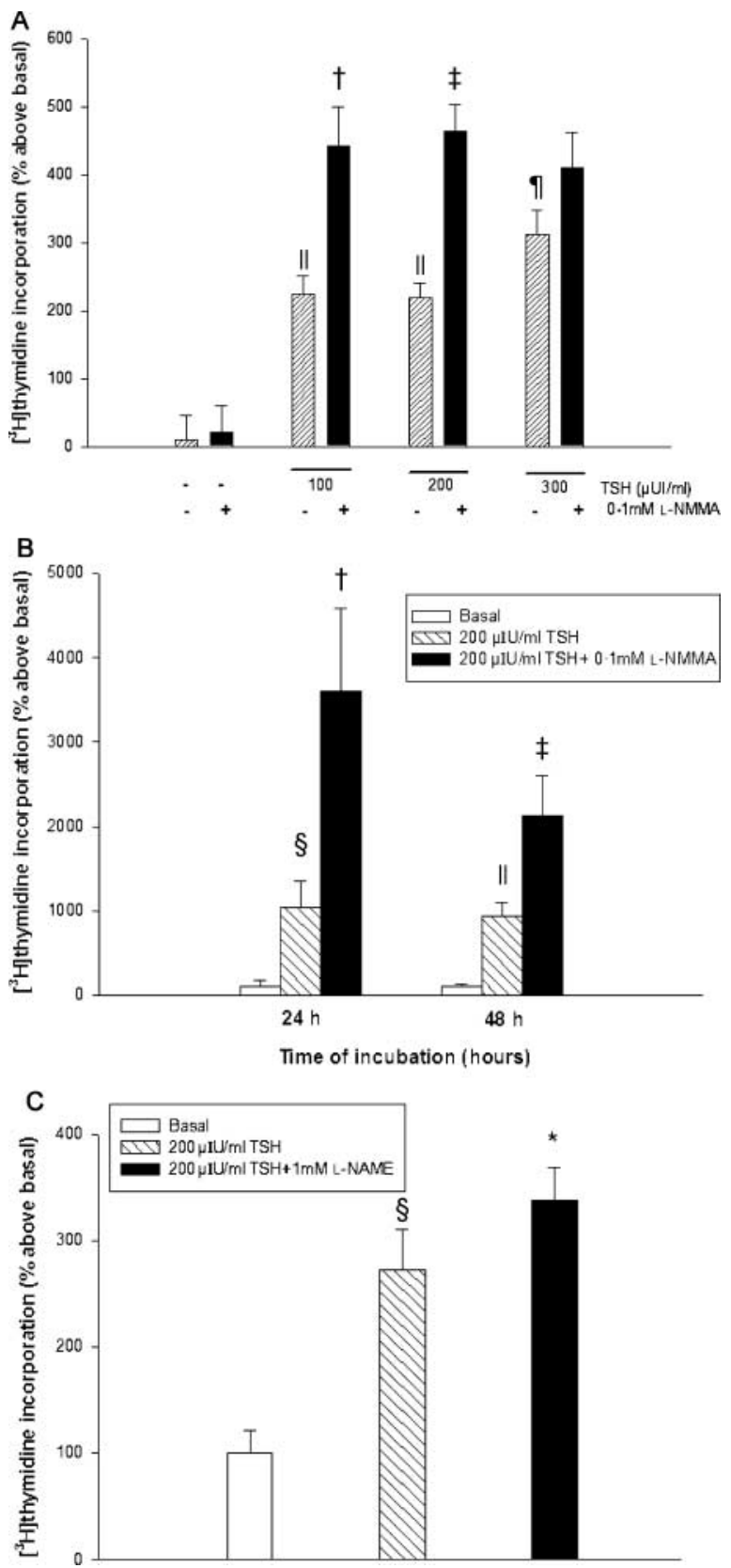

incorporation and the dye dilution assay using the intracellular fluorescent dye, CFSE.

FRTL-5 cells grown in culture medium with the addition of L-NMMA showed a significant increase of the TSH-stimulated $\left[{ }^{3} \mathrm{H}\right]$-thymidine incorporation at $24 \mathrm{~h}$ (Fig. 7A). This effect persisted at $48 \mathrm{~h}$ (Fig. 7B). We also observed an increase in $\left[{ }^{3} \mathrm{H}\right]$ thymidine incorporation by treatment of TSH-stimulated cells with L-NAME (Fig. 7C). The addition of L-NMMA or L-NAME alone did not modify $\left[{ }^{3} \mathrm{H}\right]$ thymidine incorporation compared with the basal values (Fig. 7A).

The flow cytometric analysis of CFSE-stained cells has been widely used for the study of the cell proliferation in several cell types and brings about the advantage of identifying the number of cell divisions and the number of cells that undergo cell division in a given cell population (Lyons 2000, Wang et al. 2005). We observed an increase in the number of divisions and in the proportion of cells in each phase of the cell cycle in TSH-stimulated FRTL-5 cells cultured with the addition of L-NMMA when compared with cells in the presence of TSH alone (Fig. 8A and $\mathrm{B}$ ). The addition of L-NMMA alone did not modify cell division in basal conditions (data not shown). These results are in concordance with those obtained in $\left[{ }^{3} \mathrm{H}\right]$ thymidine incorporation assays. These observations seem to indicate that the endogenously produced NO is able to reduce the TSH-induced thyroid cell proliferation.

\section{TSH stimulated the production of NO}

From these results, a role for NO in the regulation of thyroid hormone biosynthesis was suggested. Thus, it was of interest to analyse whether the endogenous NO production was TSHdependent. FRTL-5 cells were treated with different concentrations of TSH $(100,200$ and $500 \mu \mathrm{IU} / \mathrm{ml})$ for different times $(12,24$ and $48 \mathrm{~h})$ and NO generation was estimated by L$\left[{ }^{14} \mathrm{C}\right]$ citrulline production after incubation with $\mathrm{L}-\left[{ }^{14} \mathrm{C}\right]$ arginine. As depicted in Fig. 9A, incubation of cells with TSH significantly increased the $\mathrm{L}-\left[{ }^{14} \mathrm{C}\right]$ citrulline generation. The

Figure $7 \mathrm{NOS}$ inhibition increased TSH-stimulated $\left[{ }^{3} \mathrm{H}\right]$ thymidine incorporation. (A) Cells were grown for 2 days to $\sim 40 \%$ of confluence. Cells were shifted to basal medium for 4 days and then treated with TSH alone or in the presence of $0.1 \mathrm{mM}$ L-NMMA for $24 \mathrm{~h}$. Data are expressed as \% above basal (taken as 0\%; basal value $=9709$ c.p.m./well). Data represent the mean \pm s.E.M. of at least three independent experiments. (B) Cells grown as in A were treated with $200 \mu \mathrm{lU} / \mathrm{ml} \mathrm{TSH}$ with or without $0 \cdot 1 \mathrm{mM} \mathrm{L-NMMA}$ for 24 and $48 \mathrm{~h}$. Data are expressed as \% above basal (taken as $0 \%$, basal value $=1444$ c.p.m./well). Results are given as mean \pm s.D. of a representative experiment. Similar results were obtained in two additional experiments. (C) Cells grown as above were treated with $200 \mu \mathrm{lU} / \mathrm{ml}$ TSH alone or in the presence of $1 \mathrm{mM} \mathrm{L-NAME}$ for $24 \mathrm{~h}$. Data are expressed as \% above basal (taken as $0 \%$ ). Results are given as mean \pm s.D. of a representative experiment. Similar results were obtained in two additional experiments. ${ }^{*} P<0 \cdot 05,{ }^{\dagger} P<0 \cdot 01$, ${ }^{\ddagger} P<0.001$ vs TSH alone; ${ }^{\S} P<0 \cdot 05, " ~ P<0 \cdot 01,{ }^{\natural} P<0.001$ vs basal (without TSH); Student-Newman-Keuls multiple comparisons test. 
A

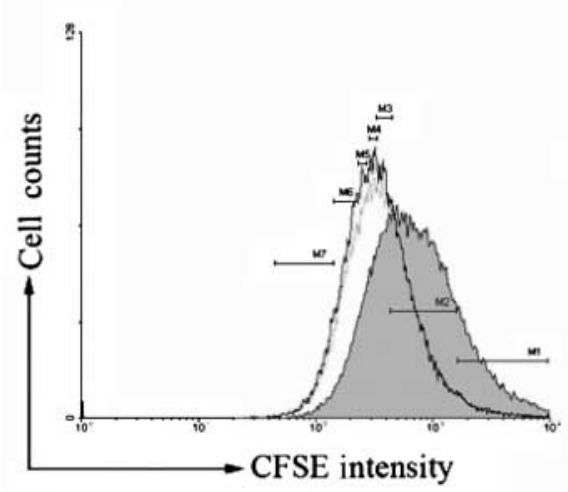

B

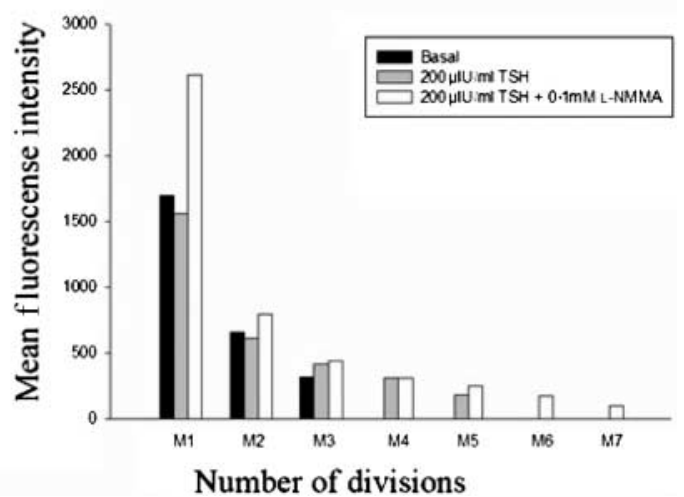

Figure 8 L-NMMA increased TSH-stimulated thyroid cell proliferation measured by CFSE labelling. FRTL-5 cells were labelled with $7 \cdot 5 \mu \mathrm{M}$ CFSE, maintained for 3 additional days in basal medium and then treated with $200 \mu \mathrm{lU} / \mathrm{ml} \mathrm{TSH}$ alone or in the presence of $0.1 \mathrm{mM}$ L-NMMA. After 3 days of culture, cells were harvested and analysed by flow cytometry. (A) Histograms of CFSE fluorescence on the horizontal axis (logarithmic scale). Markers above the peaks were used to enumerate events of each division cycle in cells cultured with L-NMMA. The stainings of basal cells (filled grey histograms), cells cultured with $200 \mu \mathrm{IU} / \mathrm{ml} \mathrm{TSH}$ alone (open light line histograms) or in the presence of $0 \cdot 1 \mathrm{mML}-\mathrm{NMMA}$ (open black line histograms) are shown for comparison. (B) The graphic shows the mean fluorescence intensity values \pm s.D. from the same data points of a representative experiment. Similar results were obtained in two additional experiments.

stimulatory effect of TSH on NO production was registered with 200 and $500 \mu \mathrm{IU} / \mathrm{ml}$ at $24 \mathrm{~h}$ (Fig. 9A). The maximal increase was observed at $24 \mathrm{~h}$ (Fig. 9B). The NOS inhibitor LNMMA was used to test specificity for the NOS-dependence of the L-citrulline increment. Pre-incubation with L-NMMA for $15 \mathrm{~min}$ abolished the $\mathrm{TSH}$-induced $\mathrm{NO}$ production (Fig. 9A and B). Incubation with L-NMMA alone did not modify L-citrulline levels (Fig. 9A). These results indicated that the NOS-mediated production of NO in the thyrocyte could be, at least in part, under TSH regulation.

\section{Discussion}

This study provides evidence that the inhibition of NOS activity is associated with an increase of TSH-stimulated iodide uptake in the thyroid cell, suggesting an inhibitory action of the endogenously produced $\mathrm{NO}$ on this essential functional step of thyroid hormone biosynthesis. The increase of NIS mRNA level that we observed under NOS inhibition seems to indicate that the NO-induced reduction of iodide uptake could be related to a diminished NIS expression. In coincidence, here, we demonstrated that the TG mRNA is increased when NOS activity is blocked, which supports a negative action of $\mathrm{NO}$ on the TG gene expression. Our observations reveal the ability of the endogenously produced $\mathrm{NO}$ to inhibit differentiated functions of thyroid cells. These findings strongly agree with the proposed mediation of NO in the cytokine-induced reduction of the TSH-stimulated TPO and thyroid oxidase (ThOX) expression observed in human thyrocytes (Gerard et al. 2006).
The action of NO is controversial and complex because this active molecule exhibits dual effects depending on its concentration and the molecular environment. As a consequence, $\mathrm{NO}$ can act as a toxic or a protective agent on different cell types (Albrecht et al. 2003, Kroncke 2003). Previous studies have reported an inhibitory effect of NO donors on differentiation markers in thyroid cells from several species (Millatt et al. 1993, Kasai et al. 1995, Bocanera et al. 1997, Costamagna et al. 1998, Lucero et al. 2005). Thus, these findings evidenced that the exogenously provided $\mathrm{NO}$ is able to produce an inhibitory action on the thyroid cell function. Coincidently, the present results support the hypothesis that the thyrocyteproduced NO could participate in a negative regulation of the thyroid hormone biosynthesis. Therefore, similar effects appear to be exerted by the endogenously produced and the exogenously supplied NO in the thyroid cell.

It has been reported that the activation of phosphoinositol/calcium cascade increased the cGMP level in dog thyroid slices (Van Sande et al. 1975, Esteves et al. 1992). This calcium-mediated cGMP production was decreased by NOS inhibition, supporting an endogenous NO-dependent cGMP accumulation (Esteves et al. 1992). The observations here obtained under blockage of cGK support the view that this kinase could be involved in the endogenous NO-mediated inhibition of iodide uptake. In accordance, a possible role of the cGMP/cGK pathway in the inhibitory effect of NO donors on iodide uptake has been proposed previously (Bocanera et al. 1997).

The increase in the functional activity of NIS and TG promoters when NOS activity is blocked indicates that NO could inhibit the TSH-induced thyroid-specific gene expression at the transcriptional level. It is well known that 


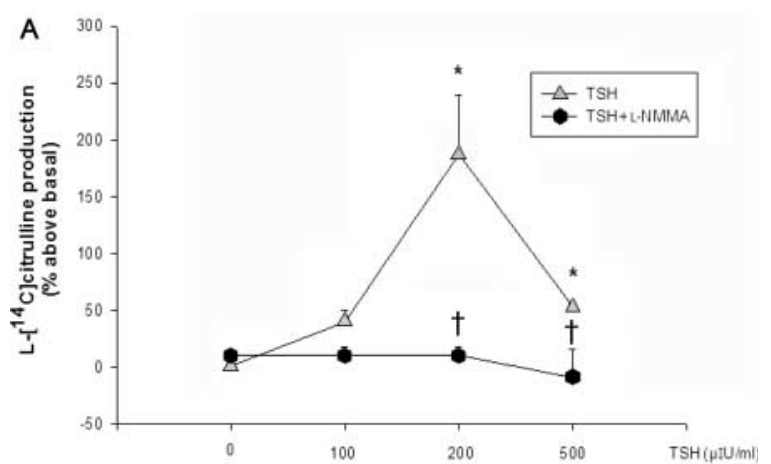

B

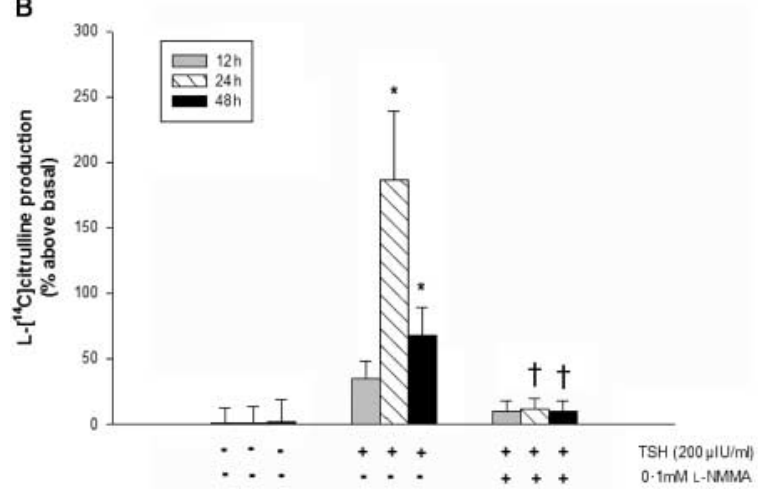

Figure $9 \mathrm{TSH}$ increased the production of $\mathrm{NO}$ in the thyroid cells. (A) Basal FRTL-5 cells were incubated with TSH $(100-500 \mu \mathrm{lU} / \mathrm{ml})$ for $24 \mathrm{~h}$. (B) Basal cells were treated with $200 \mu \mathrm{IU} / \mathrm{ml} \mathrm{TSH}$ for 12, 24 and $48 \mathrm{~h}$. To control the specificity of the response, cells were preincubated for $15 \mathrm{~min}$ with $0.1 \mathrm{mM}$ L-NMMA. Data are expressed as $\%$ above basal (taken as $0 \%$; basal value $=377$ c.p.m./ $\mu$ gDNA). Results are given as mean \pm s.E.M. of three independent experiments. ${ }^{*} P<0.05$ vs basal (without TSH, increase); ${ }^{+} P<0.05$ vs TSH alone (decrease); Student-Newman-Keuls multiple comparisons test.

the NIS and TG gene expressions are regulated by a combination of ubiquitous and thyroid-specific factors, such as thyroid transcription factor-1 (TTF-1), thyroid transcription factor-2 (TTF-2) and paired box domain transcription factor 8 ( $\operatorname{Pax} 8$ ). Several post-translational mechanisms, such as redox regulation and phosphorylation, have been demonstrated to control the activity of these factors (Kambe et al. 1996, Damante et al. 2001). Evidence is accumulating that NO preferentially modifies the activity or level of redoxsensitive transcription factors (Kroncke 2003). Then, it could be speculated that NO could partially act by modifying the activity or expression of thyroid-specific transcription factors. In favour of this hypothesis, our group recently demonstrated a NO-mediated reduction of TTF-2 mRNA expression in FRTL-5 thyroid cells (Lucero et al. 2005).

We observed an increase in the TSH-stimulated proliferation of FRTL-5 thyroid cells after disruption of NO production indicating an inhibitory effect of endogenous $\mathrm{NO}$ on cell proliferation. Controversial effects of NO on cell proliferation have been reported. In agreement with our results, the blockade of NOS activity by NOS inhibitors
(Lopez-Farre et al. 1997) or the ablation of NOS expression by antisense technology (Cartwright et al. 2000) increased endothelial cell proliferation. Contrarily, it was observed that the NO donor SNP stimulated endothelial cell proliferation (Ziche et al. 1994). Our findings show a novel property of endogenous NO to negatively regulate the TSH-induced thyroid cell proliferation.

The present study demonstrated for the first time a TSHdependent production of NO in the thyroid cell. The fact that NOS inhibitors abolished the TSH-induced NO production indicates the mediation of NOS. Interestingly, findings in some pathological thyroid tissues appear to indicate a TSH-dependent NOS expression. Thus, it has been reported that NOS III expression was augmented in hyperthyroid tissues bearing a high activity of $\mathrm{TSH}$ receptor. It was observed that NOS III immunoreactivity was progressively increased at the apical cell membrane of tissues from Graves' disease, toxic adenomas and thyrocytes from a patient with an activating mutation of the TSH receptor, whereas it was barely detectable in hypothyroid tissues (Colin et al. 1997). Surprisingly, TSH increased NO production in human aortic endothelial cells (Donnini et al. 2003).

It has been demonstrated that several mechanisms are involved in the autoregulation of thyroid function. Thus, organic iodocompounds and TG have been reported to negatively autoregulate TSH-induced differentiation parameters in the thyroid cell (Pisarev 1985, Dunn \& Dunn 2001, Eggo et al. 2003). From the present results, the endogenous NO production induced by TSH could be proposed as a possible inhibitor in the regulation of the thyroid function. In accordance, it has been reported a role of NO in modulating the function of other endocrine cells. Thus, endogenous $\mathrm{NO}$ inhibits the ACTH-stimulated aldosterone production in glomerulosa cells (Sainz et al. 2004).

In summary, the present findings provide evidence that the endogenous NO could act as a novel negative signal on the TSH-induced specific gene expression and proliferation in the thyroid cell. Since the thyroidal NO production seems to be TSH-dependent, it could be proposed to have a possible role in the regulation of thyroid cell function.

\section{Acknowledgements}

We are indebted to Drs R Di Lauro (Stazione Zoologica Anton Dohrn, University of Naples Federico II, 80121 Naples, Italy), N Carrasco (Department of Molecular Pharmacology, Albert Einstein College of Medicine, Bronx, New York 10461), P Santisteban (Instituto de Investigaciones Biomedicas Alberto Sols, Universidad Autónoma de Madrid, Arturo Duperier 4, 28029 Madrid, Spain) and T Onaya (Third Department of Internal Medicine, Faculty of Medicine, University of Yamanashi, 1110 Shimokato, Tamaho, Yamanashi 409-3898, Japan) for cDNAs and promoter constructions. This study was presented in part at the 13th International Thyroid Congress, Buenos Aires, Argentina, October 30th-November 4th (Thyroid 15:S-89, 2005). 


\section{Funding}

This study was supported by grants from the Consejo Nacional de Investigaciones Científicas y Técnicas (CONICET), Secretaría de Ciencia y Tecnología de la Universidad Nacional de Córdoba (SecyT-UNC), Agencia Córdoba Ciencia and Agencia Nacional de Promoción Científica y Tecnológica (ANPCYT-FONCYT). L F, MLV, A ML, JP N, ID $M$ and D R M are Doctoral fellows at CONICET, CIBICI. CGP and GR are established researchers at CONICET. AMMR is an established researcher at Dpto Bioq Clínica, Fac. Cs. Quim. Universidad Nacional de Córdoba. CIBICI-CONICET. The authors declare that there is no conflict of interest that would prejudice the impartiality of this scientific work.

\section{References}

Albrecht EW, Stegeman CA, Heeringa P, Henning RH \& van Goor H 2003 Protective role of endothelial nitric oxide synthase. Journal of Pathology 199 $8-17$.

Alderton WK, Cooper CE \& Knowles RG 2001 Nitric oxide synthases: structure, function and inhibition. Biochemical Journal 357 593-615.

Ambesi-Impiombato FS, Parks LA \& Coon HG 1980 Culture of hormonedependent functional epithelial cells from rat thyroids. PNAS 77 3455-3459.

Bocanera LV, Krawiec L, Silberschmidt D, Pignataro O, Juvenal GJ, Pregliasco LB \& Pisarev MA 1997 Role of cyclic 3'5' guanosine monophosphate and nitric oxide in the regulation of iodide uptake in calf thyroid cells. Journal of Endocrinology 155 451-457.

Brasier AR, Tate JE \& Habener JF 1989 Optimized use of the firefly luciferase assay as a reporter gene in mammalian cell lines. Bio Techniques 7 1116-1122.

Burton K 1956 A study of the conditions and mechanism of the diphenylamine reaction for the colorimetric estimation of deoxyribonucleic acid. Biochemical Journal 62 315-323.

Cartwright JE, Johnstone AP \& Whitley GS 2000 Endogenously produced nitric oxide inhibits endothelial cell growth as demonstrated using novel antisense cell lines. British Journal of Pharmacology 131 131-137.

Chomczynski P \& Sacchi N 1987 Single-step method of RNA isolation by acid guanidinium thiocyanate-phenol-chloroform extraction. Analytical Biochemistry 162 156-159.

Colin IM, Nava E, Toussaint D, Maiter DM, vanDenhove MF, Luscher TF, Ketelslegers JM, Denef JF \& Jameson JL 1995 Expression of nitric oxide synthase isoforms in the thyroid gland: evidence for a role of nitric oxide in vascular control during goiter formation. Endocrinology 136 5283-5290.

Colin IM, Kopp P, Zbaren J, Haberli A, Grizzle WE \& Jameson JL 1997 Expression of nitric oxide synthase III in human thyroid follicular cells: evidence for increased expression in hyperthyroidism. European Journal of Endocrinology 136 649-655.

Costamagna ME, Cabanillas AM, Coleoni AH, Pellizas CG \& Masini-Repiso AM 1998 Nitric oxide donors inhibit iodide transport and organification and induce morphological changes in cultured bovine thyroid cells. Thyroid 8 1127-1135.

Dai G, Levy O \& Carrasco N 1996 Cloning and characterization of the thyroid iodide transporter. Nature 379 458-460.

Damante G, Tell G \& Di Lauro R 2001 A unique combination of transcription factors controls differentiation of thyroid cells. Progress in Nucleic Acid Research and Molecular Biology 66 307-356.

Di Lauro R, Obici S, Acquaviva AM \& Alvino CG 1982 Construction of recombinant plasmids containing rat thyroglobulin mRNA sequences. Gene 19 117-125.

Donnini D, Ambesi-Impiombato FS \& Curcio F 2003 Thyrotropin stimulates production of procoagulant and vasodilative factors in human aortic endothelial cells. Thyroid 13 517-521.
Dunn JT \& Dunn AD 2001 Update on intrathyroidal iodine metabolism. Thyroid 11 407-414.

Eggo MC, Quiney VM \& Campbell S 2003 Local factors regulating growth and function of human thyroid cells in vitro and in vivo. Molecular and Cellular Endocrinology 213 47-58.

Endo T, Kaneshige M, Nakazato M, Ohmori M, Harii N \& Onaya T 1997 Thyroid transcription factor-1 activates the promoter activity of rat thyroid $\mathrm{Na}+$ /I- symporter gene. Molecular Endocrinology 11 1747-1755.

Esteves RZ, van Sande J \& Dumont JE 1992 Nitric oxide as a signal in thyroid. Molecular and Cellular Endocrinology 90 R1-R3.

Garcia B \& Santisteban P 2002 PI3K is involved in the IGF-I inhibition of TSH-induced sodium/iodide symporter gene expression. Molecular Endocrinology 16 342-352.

Gerard AC, Boucquey M, van den Hove MF \& Colin IM 2006 Expression of TPO and ThOXs in human thyrocytes is downregulated by IL1alpha/IFN-gamma, an effect partially mediated by nitric oxide. American Journal of Physiology 291 E242-E253.

Grider JR 1993 Interplay of VIP and nitric oxide in regulation of the descending relaxation phase of peristalsis. American Journal of Physiology 264 G334-G340.

Guix FX, Uribesalgo I, Coma M \& Muñoz FJ 2005 The physiology and pathophysiology of nitric oxide in the brain. Progress in Neurobiology 76 126-152

Kambe F, Nomura Y, Okamoto T \& Seo H 1996 Redox regulation of thyroid-transcription factors, Pax- 8 and TTF-1, is involved in their increased DNA-binding activities by thyrotropin in rat thyroid FRTL-5 cells. Molecular Endocrinology 10 801-812.

Kang HC, Ohmori M, Harii N, Endo T \& Onaya T 2001 Pax8 is essential for regulation of the thyroglobulin gene by transforming growth factor-beta1. Endocrinology 142 267-275.

Kasai K, Hattori Y, Nakanishi N, Manaka K, Banba N, Motohashi S \& Shimoda S 1995 Regulation of inducible nitric oxide production by cytokines in human thyrocytes in culture. Endocrinology 136 4261-4270.

Kohn LD \& Valente WA 1989 FRTL-5 Manual: a current guide. In FRTL-5 Today, pp 243-273. Eds FS Ambesi-Impiombato \& H Perrild. Amsterdam: Elsevier Sciences Publisher BV Biomedical Division.

Kroncke KD 2003 Nitrosative stress and transcription. Biological Chemistry 384 1365-1377.

Krumenacker JS, Hanafy KA \& Murad F 2004 Regulation of nitric oxide and soluble guanylyl cyclase. Brain Research Bulletin 62 505-515.

Laskin JD, Heck DE \& Laskin DL 1994 Multifunctional role of nitric oxide in inflammation. Trends in Endocrinology and Metabolism 5 377-382.

Lopez-Farre A, Sánchez de Miguel L, Caramelo C, Gomez-Macias J, Garcia R, Mosquera JR, de Frutos T, Millas I, Rivas F, Echezarreta G et al. 1997 Role of nitric oxide in autocrine control of growth and apoptosis of endothelial cells. American Journal of Physiology 272 H760-H768.

Lucero AM, Velez ML, Fozzatti L, Nicola JP, Pellizas CG, Coleoni AH \& Masini-Repiso AM 2005 Nitric oxide inhibits thyroperoxidase gene expression at transcriptional level by involving TTF-2 thyroid transcription factor in FRTL-5 cells. Thyroid 15 S-85 (Abstract).

Lyons AB 2000 Analysing cell division in vivo and in vitro using flow cytometric measurement of CFSE dye dilution. Journal of Immunological Methods 243 147-154.

Millatt LJ, Jackson R, Williams BC \& Whitley GS 1993 Nitric oxide stimulates cyclic GMP in human thyrocytes. Journal of Molecular Endocrinology 10 163-169.

Nathan C \& Xie QW 1994 Regulation of biosynthesis of nitric oxide. Journal of Biological Chemistry 269 13725-13728.

Pisarev MA 1985 Thyroid autoregulation. Journal of Endocrinological Investigation 8 475-484.

Sainz JM, Reche C, Rabano MA, Mondillo C, Patrignani ZJ, Macarulla JM, Pignataro OP \& Trueba M 2004 Effects of nitric oxide on aldosterone synthesis and nitric oxide synthase activity in glomerulosa cells from bovine adrenal gland. Endocrine 24 61-71.

Sambrook J, Fritsch EF \& Maniatis T 1989 Molecular cloning. A Laboratory Manual, edn 2, Cold Spring Harbor, NY: Cold Spring Harbor Laboratory. 
Van Sande J, Decoster C \& Dumont J 1975 Control and role of cyclic $3^{\prime}, 5^{\prime}$-guanosine monophosphate in the thyroid. Biochemical and Biophysical Research Communications 62 168-175.

Vélez ML, Costamagna E, Kimura ET, Fozzatti L, Pellizas CG, Montesinos MM, Lucero AM, Coleoni AH, Santisteban P \& Masini-Repiso AM 2006 Bacterial lipopolysaccharide stimulates the thyrotropin-dependent thyroglobulin gene expression at the transcriptional level by involving the transcription factors thyroid transcription factor- 1 and paired box domain transcription factor 8. Endocrinology 147 3260-3275.

Wang XQ, Duan XM, Liu LH, Fang YQ \& Tan Y 2005 Carboxyfluorescein diacetate succinimidyl ester fluorescent dye for cell labelling. Acta Biochimica et Biophysica Sinica 37 379-385.
Ziche M, Morbidelli L, Masini E, Amerini S, Granger HJ, Maggi CA, Geppetti P \& Ledda F 1994 Nitric oxide mediates angiogenesis in vivo and endothelial cell growth and migration in vitro promoted by substance $\mathrm{P}$. Journal of Clinical Investigation 94 2036-2044.

Received in final form 30 November 2006 Accepted 21 December 2006 Made available online as an Accepted Preprint 27 December 2006 